\title{
PRACTICAL ASPECTS OF OSAI METHODOLOGY IN ASSESSING THE ORGANIZATIONAL CULTURE OF AN ENGINEERING COMPANY
}

\author{
Aleksandra BILETSKAYA ${ }^{1}$, \\ Khmelnitsky National University, Ukraine
}

\begin{abstract}
This article is intended to generalize and highlight the practical application of certain science-based approaches to assessment of an engineering company's organizational culture. The OSAI method application has enabled determining the type of the organizational culture existing within a company and the desirable type thereof, i.e. the one which would produce a positive effect on the competitive status of a company, as well as on the utilization of its human resources. This is important because an appropriate level of the organizational culture within a company would enhance the psychological climate within a company and would provide an opportunity for improving its performance. Methodology. In order to attain the goal of our research, it is necessary to diagnose the type of the organizational culture of some selected companies and draw a conclusion as to amendment of their organizational culture. In order to ensure the successful outcome of the corporate organizational culture diagnosing procedure, let us use the OSAI tool to determine the foundation of such culture. This organizational culture assessment tool helps to define the organizational culture which members of a company are to achieve in order to meet the demands and to respond to the dynamic changes in the business environment. The results showed that the assessment of organizational culture using the method made it possible to determine the OSAI required type of organizational culture on the test plants. Practical implications. Definition of recommendation type of organizational culture has enabled the leadership to change the style of his behavior and better motivate the labor collective. Pay attention to the existing problems and improve the psychological atmosphere in the team, as well as improve the efficiency of plant personnel. Value/originality. The data obtained for the four businesses lead to the conclusion that it is the method of evaluation the optimum procedure for organizational culture assessment.
\end{abstract}

Key words: organizational culture, type of culture, method of evaluation, engineering company, level of the organizational culture.

JEL Classification: M14, O14, D23

\section{Introduction}

Most scholars and analysts, involved in the business organization domain, now realize that the organizational culture produces a dramatic effect on the operating performance and long-term efficiency of a company. The empirical studies (Cameron, Kim S. andEttington, Deborah R., 1988; Denison, Daniel, Hooijberg, Robert, and Quinn, Robert E., 1995; Trice, Harrison and Beyer, Janice, 1993) demonstrate the magnitude of the organizational culture impact on improvement of business performance. One of the publications (Kotter, John P. and Heskett, James L., 1992) highlights the results of interviewing the reputed financial analysts who were engaged in surveillance over performance of certain businesses.

Each of the analysts has compared the performance of twelve most prosperous companies with that of ten lower-level companies. Although the job of an analyst is somewhat typical by nature inasmuch as it is almost exclusively based on some firmly established data, only one of the seventy five analysts maintains that the culture produces little effect, if any, on business performance. All others confirm that culture is a determining factor in longterm financial well-being of a company.

\section{Review of Recent Studies and Publications}

In the course of the studies, it has been found out that organizational culture has a great influence on employees, e.g. their moral stature, commitment, productivity, physical health and emotional state and other things (Kozlowski, Steve W.J., Chao, Georgia T., Smith, Eleanor M., and Hedlund, Jennifer, 1993). Hence, organizational culture is organically associated with personnel behavior.

An urgent need for a cultural change in nowadays business arises out of chaotic external fluctuations, which imperil the well-being of a company unless it updates its organizational culture.

Over the past two decades, a number of various techniques have been suggested to assess the organizational 
culture essential features. A detailed review of research papers on the topic in question can be found in the works of such authors as (Cameron, Kim S. and Ettington, Deborah R., 1988; Cameron, Kim S., 1997; Martin, Joanne, 1992; Hooijberg, Robert and Petrock, Frank, 1993). Some of the measurements, as provided in the literature, are mentioned for illustration only, e.g. in (Martin, Joanne, 1992), and belong to the authors who maintain that the solidity and consistency of culture are the major definitive attributes thereof.

S. Albert and D. Whetten (Alpert, Stuart and Whetten, David A., 1985) believe that measuring from the purely personal scale up to corporate scale is critical for culture assessment. D.R. Arnold and L.M. Capella ( propose to evaluate the strong and weak points of organizational culture, as well as to assess its inward-and- outward focus.

\section{Objective of the Article}

The Article sums up the results of research on the sciencebased practices fit for assessment of the organizational culture of an engineering company.

\section{Basic Research Material}

To determine the most important factors that are worth considering, it is necessary to have an acceptable framework, a kind of theoretical foundation that would allow to narrow the scope of search and to focus right on the key factors of organizational culture assessment. Obviously, none of assessment frameworks can be found fully compatible, just as it is impossible to prove that any of them are true, while others have no right to exist. . The most acceptable frameworks should base on the empirical proof and allow for integration and arrangement, within its structure, the majority of measurements offered by the science.

The key issues that the results of an organizational culture assessment should address are the organizational culture efficiency criteria, organizational efficiency factors, organizational culture indicators, etc.

S. Robbins (Voronkova A., Babiak M., 2006) proposes to consider the organizational culture based on the features most valued in the company. I. V. Mazhura offers an indicative method to assess the company culture. The indicative assessment procedure used to evaluate the strength of corporate culture has a number of special features. First, such assessment covers the established quality indicators; second, it is based on expert surveys, third, such assessment depends on the personal view of the person involved. The qualitative nature of indicative assessment of the strength of corporate culture brings about certain assessment-related difficulties, for it is not always clear which level of culture (high or low) is shown or testified to by a particular indicator. After establishing the culture indicators, the next necessary step is to formulate the criteria whereby such indicators can tell whether the corporate culture is strong or weak. That is, each of the indicators should have a number of clearly defined criteria that can testify to its level.
Based on such criteria, it is possible to conduct an indicative assessment of corporate culture elements. Obviously, such concept as corporate culture covers all functional areas of a business and relates to each of its employees. For this reason, a group of experts involved in assessment of corporate culture strength, must consist of representatives of different functional groups, in order to avoid any biased result.

Another approach to evaluating corporate culture has been developed K. Cameron and R. Quinn (Cameron K., Quinn R., 2001). They propose to evaluate corporate culture in two dimensions. The first one characterizes the degree of flexibility within the range from the organizational versatility and plasticity, on the one hand, to the organizational rigidity and durability, on the other. The second dimension differentiates between the inward criteria, which testify to internal orientation, integration and unity and the outward criteria associated with an external focus, differentiation and competitiveness. The two dimensions generate four quadrants, each representing a clear set of organizational performance indicators. The authors define each of the quadrants on the basis of its intrinsic features: clan adhocracy, market and hierarchy. K. Cameron and R. Quinn offer an organizational culture assessment tool (OSAI), in the form of a questionnaire, which requires an individual response to six questions (items).

This organizational culture assessment tool ensures an effective and thorough diagnosis of those important aspects of a business which define the foundation of its organizational culture. The purpose of the said assessment tool is to assist in identifying the existing corporate culture. Moreover, this tool helps to define the organizational culture which members of a company are to achieve in order to meet the demands and to respond to the dynamic changes in the business environment.

The tool proposed for assessing the corporate organizational culture focuses on the core features of the organizational culture of a company. The rating score, as given in Table, below, implies the predominance of certain types of culture in the company in question. To construct a profile of the current and desirable organizational culture in the company under analysis, one should use the estimates, calculated according to Table 2 below. The process of constructing the organizational culture profiles of a company includes the two following phases.

Phase 1. Construction of corporate organizational culture profiles.

1. First, analyze the values under the Current State column. Apply the average score for each alternative (A, B, $\mathrm{C}$ and D) to the diagram pattern (Cameron, Kim S., 1997). The alternative $A$ value stands for the clan culture. The relevant value of the Alternative $A$ is found on the diagonal line stretching upward to the top left quadrant of the pattern. The alternative $B$ value stands for the adhocratic culture. The relevant value of the Alternative B is found on the diagonal line going up to the top right quadrant. 
The alternative $\mathrm{C}$ value stands for the Market-Oriented Culture. The relevant value is found on the diagonal line going down to the lower right quadrant of the pattern. The alternative $\mathrm{D}$ value stands for the hierarchal culture. The relevant value is found on the diagonal line going down to the lower left quadrant.

Connect the points marked in each quadrant together to make up a quadrangle. The resultant profile depicts the existing organizational culture in the company under analysis (the profile of the culture, as perceived by an expert right now). It is more useful for the diagnostic purpose, since the researcher is able to see immediately the strongest and weakest points in the organizational culture of the company in question.

2. Having completed the existing organizational culture profile for the company in question, proceed constructing the desirable organizational culture profile according to the score under the Desirable State column. Apply the average score for each alternative (A, B, C and D) to the diagram pattern. Hence, we obtain the desirable organizational culture profile for the company in question.

3. Having constructed tye nexisting and desirable organizational culture profiles, analyze the profiles to determine the type-of-culture parameters, to ascertain the strength of the prevailing type of culture, as well as the culture consistency, uniformity, whatever.

Phase II. Analysis of corporate organizational culture profiles.

2.1. Comparison of the current and desirable corporate organizational culture profiles. To analyse the constructed profiles of corporate organizational culture, it is advisable to superpose them within one picture. Positioning of the two diagrams within one picture allows to compare how the existing culture conforms to the desirable culure, as well as to determine how the existing culture can be modified to achieve such conformity. By analyzing the areas, where the organizational culture profiles differ most of all, it is possible to identify a kind of road map changes.

In order to attain the goal of our research, it is necessary to diagnose the type of the organizational culture of some selected companies and draw a conclusion as to amendment of their organizational culture. In order to ensure the successful outcome of the corporate organizational culture diagnosing procedure, let us use the OSAI tool to determine the foundation of such culture.

One of the most important steps in diagnosing the organizational culture is the choice of experts. In our case, such experts are the CEOs of the companies in question. To obtain the results required for the analysis, we have prepared questionnaires containing the questions which require individual answers under six items. We estimate the prevalence, in per cent, of the characteristics in the following areas: the major characteristics of the company; the overall style of leadership in the organization; human resource management; uniting capacity of the organization; strategic goals; success criteria. Each of the six questions that are contained in the OSAI tool suggests four alternative answers. According to the questioning results and using a 100-point scale, we estimate the significance of the four alternatives in the weight ratio, which suits best for the company in question. The alternative that most closely resembles the situation in the company receives the maximum number of points. The maximum number of points along the line $\mathrm{A}$ indicates the clan culture; line B the adhocratic culture, line $\mathrm{C}$ the Market-Oriented Culture, and line D the hierarchical culture in the company in question (Cameron, Kim S. and Ettington, Deborah R., 1988).

See an example of the organizational culture type diagnosing in Tables $1 \ldots 3$ below. As is seen from Table 1 , the respondents believe that the most important characteristics of all analyzed companies have to change. For NOVATOR State-Owned Company, they have to increase along the $\mathrm{A}$ and $\mathrm{C}$ lines and have to decrease

Table 1

Assessment of Major Characteristics

\begin{tabular}{|c|c|c|c|c|c|c|c|c|c|}
\hline \multirow[t]{2}{*}{ Direction } & \multirow[t]{2}{*}{ Major Characteristics } & \multicolumn{2}{|c|}{$\begin{array}{c}\text { Novator State- } \\
\text { Owned Company }\end{array}$} & \multicolumn{2}{|c|}{ Temp JSC } & \multicolumn{2}{|c|}{$\begin{array}{c}\text { Ukr Elektro Aparat } \\
\text { JSC }\end{array}$} & \multicolumn{2}{|c|}{$\begin{array}{c}\text { Krasyliv Machine } \\
\text { Building Factory JSC }\end{array}$} \\
\hline & & Now & Desirable & Now & Desirable & Now & Desirable & Now & Desirable \\
\hline A & $\begin{array}{l}\text { The Company is unique for its } \\
\text { characteristics. It is like a large } \\
\text { family. People seem to have much in } \\
\text { common }\end{array}$ & 16.7 & 41.6 & 7.5 & 47.5 & 14.2 & 33.3 & 32.5 & 36.7 \\
\hline B & $\begin{array}{l}\text { The Company is a very dynamic } \\
\text { business. People are willing to } \\
\text { sacrifice themselves and bear risks }\end{array}$ & 10.8 & 26.7 & 27.5 & 23.3 & 13.3 & 35 & 25.8 & 27.5 \\
\hline $\mathrm{C}$ & $\begin{array}{l}\text { A result -oriented company. Task } \\
\text { fulfillment is the primary concern. } \\
\text { People focus on competition and } \\
\text { goal achievement. }\end{array}$ & 29.2 & 16.7 & 30 & 13.4 & 31.7 & 21.7 & 20 & 15.8 \\
\hline $\mathrm{D}$ & $\begin{array}{l}\text { A rigidly structured and highly } \\
\text { controlled company. As a rule, people } \\
\text { follow formal procedures. }\end{array}$ & 43.3 & 15 & 35 & 15.8 & 40.8 & 10 & 21.7 & 20 \\
\hline & Total & 100 & 100 & 100 & 100 & 100 & 100 & 100 & 100 \\
\hline
\end{tabular}


Vol. 1, 2015

Table 2

As-it-is Estimates

\begin{tabular}{|c|c|c|c|c|c|c|c|c|c|}
\hline \multicolumn{5}{|c|}{ Clan Culture } & \multicolumn{5}{|c|}{ Adhocratic Culture } \\
\hline Responses & $\begin{array}{c}\text { Novator } \\
\text { State- } \\
\text { Owned } \\
\text { Company }\end{array}$ & $\begin{array}{c}\text { Temp } \\
\text { JSC }\end{array}$ & $\begin{array}{l}\text { Ukr Elektro } \\
\text { Aparat JSC }\end{array}$ & KMBFJSC & Responses & $\begin{array}{c}\text { Novator } \\
\text { State- } \\
\text { Owned } \\
\text { Company }\end{array}$ & $\begin{array}{c}\text { Temp } \\
\text { JSC }\end{array}$ & $\begin{array}{l}\text { Ukr Elektro } \\
\text { Aparat JSC }\end{array}$ & KMBFJSC \\
\hline $1 \mathrm{~A}$ & 20 & 5 & 20 & 35 & $1 \mathrm{~B}$ & 10 & 20 & 5 & 15 \\
\hline $2 \mathrm{~A}$ & 25 & 10 & 5 & 35 & $2 B$ & 5 & 25 & 10 & 25 \\
\hline $3 \mathrm{~A}$ & 15 & 10 & 10 & 20 & $3 \mathrm{~B}$ & 5 & 15 & 20 & 35 \\
\hline $4 \mathrm{~A}$ & 20 & 5 & 15 & 40 & $4 \mathrm{~B}$ & 20 & 35 & 30 & 20 \\
\hline $5 \mathrm{~A}$ & 10 & 10 & 10 & 25 & $5 \mathrm{~B}$ & 15 & 20 & 15 & 40 \\
\hline $6 \mathrm{~A}$ & 10 & 5 & 5 & 40 & $6 \mathrm{~B}$ & 10 & 30 & 10 & 20 \\
\hline $\begin{array}{c}\text { Total (A } \\
\text { Responses) }\end{array}$ & 100 & 45 & 85 & 195 & $\begin{array}{c}\text { Total (B } \\
\text { Responses) }\end{array}$ & 65 & 165 & 80 & 155 \\
\hline $\begin{array}{l}\text { Average (total } \\
\text { divided by } 6 \text { ) }\end{array}$ & 16.7 & 7.5 & 14.2 & 32.5 & $\begin{array}{l}\text { Average (total } \\
\text { divided by } 6 \text { ) }\end{array}$ & 10.8 & 27.5 & 13.3 & 25.8 \\
\hline \multicolumn{5}{|c|}{ Market-Oriented Culture } & \multicolumn{5}{|c|}{ Hierarchical Culture } \\
\hline $1 \mathrm{C}$ & 30 & 20 & 35 & 15 & $1 \mathrm{D}$ & 40 & 50 & 20 & 25 \\
\hline $2 \mathrm{C}$ & 25 & 15 & 30 & 25 & $2 \mathrm{D}$ & 45 & 25 & 35 & 15 \\
\hline $3 \mathrm{C}$ & 30 & 10 & 40 & 20 & $3 \mathrm{D}$ & 50 & 15 & 50 & 25 \\
\hline $4 \mathrm{C}$ & 35 & 25 & 35 & 10 & $4 \mathrm{D}$ & 25 & 40 & 40 & 10 \\
\hline $5 \mathrm{C}$ & 25 & 35 & 25 & 15 & $5 \mathrm{D}$ & 50 & 15 & 55 & 45 \\
\hline $6 \mathrm{C}$ & 30 & 10 & 45 & 35 & $6 \mathrm{D}$ & 50 & 10 & 50 & 10 \\
\hline $\begin{array}{c}\text { Total }(\mathrm{C} \\
\text { responses })\end{array}$ & 175 & 180 & 190 & 120 & $\begin{array}{c}\text { Total }(\mathrm{D} \\
\text { responses) }\end{array}$ & 260 & 210 & 245 & 130 \\
\hline $\begin{array}{l}\text { Average (total } \\
\text { divided by } 6 \text { ) }\end{array}$ & 29.2 & 30 & 31.7 & 20 & $\begin{array}{l}\text { Average (total } \\
\text { divided by 6) }\end{array}$ & 43.3 & 35 & 40.8 & 21.7 \\
\hline
\end{tabular}

Table 3

Desirable Estimates

\begin{tabular}{|c|c|c|c|c|c|c|c|c|c|}
\hline \multicolumn{5}{|c|}{ Clan Culture } & \multicolumn{5}{|c|}{ Adhocratic Culture } \\
\hline Responses & $\begin{array}{l}\text { Novator } \\
\text { State- } \\
\text { Owned } \\
\text { Company }\end{array}$ & $\begin{array}{c}\text { Temp } \\
\text { JSC }\end{array}$ & $\begin{array}{l}\text { Ukr Elektro } \\
\text { Aparat JSC }\end{array}$ & KMBFJSC & Responses & $\begin{array}{l}\text { Novator } \\
\text { State- } \\
\text { Owned } \\
\text { Company }\end{array}$ & $\begin{array}{c}\text { Temp } \\
\text { JSC }\end{array}$ & $\begin{array}{l}\text { Ukr Elektro } \\
\text { Aparat JSC }\end{array}$ & KMBFJSC \\
\hline $1 \mathrm{~A}$ & 40 & 50 & 45 & 35 & $1 \mathrm{~B}$ & 35 & 20 & 45 & 15 \\
\hline $2 \mathrm{~A}$ & 45 & 45 & 25 & 40 & $2 \mathrm{~B}$ & 25 & 10 & 25 & 35 \\
\hline $3 \mathrm{~A}$ & 30 & 50 & 15 & 25 & $3 \mathrm{~B}$ & 15 & 35 & 15 & 20 \\
\hline $4 \mathrm{~A}$ & 25 & 40 & 35 & 10 & $4 \mathrm{~B}$ & 25 & 25 & 35 & 40 \\
\hline $5 \mathrm{~A}$ & 50 & 50 & 25 & 35 & $5 B$ & 10 & 15 & 25 & 25 \\
\hline $6 \mathrm{~A}$ & 50 & 50 & 25 & 45 & $6 \mathrm{~B}$ & 20 & 5 & 35 & 0 \\
\hline $\begin{array}{c}\text { Total (A } \\
\text { Responses) }\end{array}$ & 250 & 285 & 200 & 220 & $\begin{array}{c}\text { Total (B } \\
\text { Responses) }\end{array}$ & 160 & 140 & 210 & 165 \\
\hline $\begin{array}{c}\text { Average (total } \\
\text { divided by } 6 \text { ) }\end{array}$ & 41.6 & 47.5 & 33.3 & 36.7 & $\begin{array}{l}\text { Average (total } \\
\text { divided by } 6 \text { ) }\end{array}$ & 26.7 & 23.3 & 35 & 27.5 \\
\hline \multicolumn{5}{|c|}{ Market-Oriented Culture } & \multicolumn{5}{|c|}{ Hierarchical Culture } \\
\hline $1 \mathrm{C}$ & 25 & 10 & 35 & 5 & $1 \mathrm{D}$ & 15 & 25 & 10 & 25 \\
\hline $2 \mathrm{C}$ & 15 & 5 & 25 & 15 & $2 \mathrm{D}$ & 10 & 5 & 10 & 15 \\
\hline $3 \mathrm{C}$ & 30 & 10 & 20 & 25 & $3 \mathrm{D}$ & 10 & 10 & 5 & 20 \\
\hline $4 \mathrm{C}$ & 15 & 15 & 15 & 30 & $4 \mathrm{D}$ & 25 & 15 & 5 & 20 \\
\hline $5 \mathrm{C}$ & 10 & 20 & 25 & 5 & $5 \mathrm{D}$ & 15 & 25 & 10 & 25 \\
\hline $6 \mathrm{C}$ & 5 & 25 & 10 & 5 & $6 \mathrm{D}$ & 20 & 10 & 20 & 15 \\
\hline $\begin{array}{c}\text { Total (C } \\
\text { Responses) }\end{array}$ & 100 & 80 & 130 & 95 & $\begin{array}{c}\text { Total (D } \\
\text { Responses) }\end{array}$ & 90 & 95 & 60 & 120 \\
\hline $\begin{array}{l}\text { Average (total } \\
\text { divided by } 6 \text { ) }\end{array}$ & 16.7 & 13.4 & 21.7 & 15.8 & $\begin{array}{l}\text { Average (total } \\
\text { divided by } 6 \text { ) }\end{array}$ & 15 & 15.8 & 10 & 20 \\
\hline
\end{tabular}


along the $\mathrm{B}$ and $\mathrm{D}$ lines. For Temp JSC, the most important characteristics along $\mathrm{C}$ and $\mathrm{D}$ lines should increase in the future; along the line $\mathrm{B}$, in the respondents' opinion, they should remain where they are; whereas along the line A, they can be somewhat reduced. As to Krasyliv MachineBuilding Factory JSC, the respondents believe that the major characteristics along the lines $\mathrm{A}, \mathrm{B}$ and $\mathrm{C}$ should increase, while along the line $\mathrm{D}$, they should decrease.

Likewise, organizational culture is diagnosed in other five areas: the overall style of leadership; human resource management; uniting capacity of the organization; strategic goals; success criteria. To ascertain the type of the organizational culture, the resultant data are grouped in Tables 2 and 3 below. As a result of the diagnosis carried out by us, we are able to define the existing and the desirable type of the organizational culture in the companies in question.

As is clear from Table 2, Krasyliv Machine-Building Factory JSC has got the adhocratic type of organizational culture where the average score is 32.5 , so, in the future, it is desirable to reduce the influence of the adhocratic culture and pay attention to forming the clan culture which can be described as follows:

- friendly relations between employees, they have much in common;

- the company looks like a large family;

- the company leaders and managers are perceived as tutors;

- the company exists thanks to the dedication and traditions;

- high responsibility in running the company's business, focus on the long-term benefits from self-improvement of individuals, high degree of importance is attached to the staff unity and morale;

- success means a good attitude to customers and care about the welfare of employees;

- encouraged team work and participation of employees in the company's business.

The fact that the respondents rate the clan culture manifestations in Krasyliv Machine Building Factory JSC (KMBF) at 32.5 points (preferably 36.7 ) shows that, in the future, the current state of the company's organizational culture needs to change towards the clan culture.

The results of the research carried out to ascertain the type of organizational culture existing at Ukr Elektro Aparat JSC testify to the fact that the hierarchical culture prevails there now, its average score being 40.8 ; however, in the future, it is desirable to start creating the adhocratic type of organizational culture, its average score now being 13.3 (preferably 35).

NOVATOR State-Owned Company and Temp JSC are the companies where the hierarchical type of culture prevails: 43.3 and 35, respectively. However, the results of the survey demonstrate the need for transition to the clan type of organizational culture, the average score of which is now 41.6 for NOVATOR and 47.5 for Temp.

The said companies have established the hierarchical type of organizational culture, which is characterized by the following features: formalized and structured place of work;

- the production process is governed by the procedure;

- the leaders are proud of their being the thinking coordinators and organizers;

smooth running business is of utmost importance;

the company is united by formal rules and official policy;

- the company's long-term needs lie maintaining the stability, smooth running and profitability of its operations; - the success is defined in terms of reliability of supply, faultless adherence to calendar schedules and low expenses;

- the human resources are managed on the basis of guaranteed occupation and long-term predictability.

The companies lack the friendly-family atmosphere, which is typical for the clan culture. In general, the companies in question should, in the future, get rid of the prevalence of the hierarchical or clan type of organizational culture and pay more attention to the development of the market-oriented organizational culture, which is characterized by the following features:

- the company is focused on results, its main concern is to accomplish the pre-planned task;

- the employees are determined to achieve and compete; - the leaders are firm managers and competitors; they do not spare themselves and demand from their subordinates;

- organization is a unity in its desire to win;

- good reputation and success is a common concern;

- the far-reaching strategy focuses on competitiveness, fulfillment of tasks and achievement of goals;

- the success is defined in terms of secured promotion to the market and increase of the market share;

- the competitive pricing and market leadership are of primary importance;

- the style of business is the hard-line competitivenessupgrading policy.

The advantages of this method of assessment are as follows. First, it is quite easy to determine the type of organizational structure. Second, the research is carried out along a fixed number of trends and performance criteria. Third, the offered assessment method makes it possible to find out certain areas where the organizational culture ensues from and where it functions.

\section{Conclusion}

Findings and suggestions. Generally speaking, the method elaborated by the author, as well as its components, tools and suggestions may be taken into consideration in developing a comprehensive technique for assessment of the organizational culture of a company. However, such assessment technique should not wholly rely on the methods and procedures offered by the author, inasmuch as there are some proven practices and methods used to assess corporate organizational culture. Therefore, it is advisable to pursue a balanced approach combining the benefits of all existing methods, including this one, in developing the optimum procedure for organizational culture assessment. 


\section{References}

Voronkova, A.E., Babiak, M.M., Koreniev, Ye.N., Mazhura, I.V. (2006) Corporations: Management and Culture. Monography. - Drogobych. "Vymir". - 376 p.

Cameron, K., Quinn, R., "Diagnosing and Changing Organizational Culture” / Translated from English under the editorship of Andreeva. - SPb: Piter, 2001. - 320 p.

Alpert, Stuart and Whetten, David A. (1985) "Organizational identity", Research in Organizational Behavior, 7:263-502.

Cameron, Kim S. and Ettington, Deborah R. (1988) The conceptual Foundations of organizational culture. Higher Education: Handbook of Theory and Research, p. 356-396. New York: Agathon.

Cameron, Kim S. (1997) Techniques for making organizations effective: Some popular approaches. Enhancing Organizational Performance. Washington D.C.: National Academy Press.

Denison, Daniel, Hooijberg, Robert, and Quinn, Robert E. (1995) Paradox and performance: Toward a theory of behavioral complexity in managerial leadership. Organizational Science, 6:524-540.

Kotter, John P. and Heskett, James L. (1992) Corporate Culture and Performance // New York: Free Press.

Kozlowski, Steve W.J., Chao, Georgia T., Smith, Eleanor M., and Hedlund, Jennifer (1993) Organizational downsizing: Strategies, interventions, and research implications. International Review of Industrial and Organizational Psychology, 8:263-332.

Martin, Joanne (1992) Cultures in Organizations. New York: Oxford University Press, 1:339-359.

Hooijberg, Robert and Petrock, Frank (1993) On cultural change: Using the competing values framework to help leaders to a transformational strategy. Human Resource Management, 32: 29-51.

Trice, Harrison and Beyer, Janice (1993) The Cultures of Work Organizations. Englewood Cliffs, NJ: Prentice Hall.

\section{Александра БИЛЕЦКАЯ}

\section{ПРАКТИЧЕСКИЕ АСПЕКТЫ ИСПОЛЬЗОВАНИЯ МЕТОДИКИ ОСАИ В ОЦЕНКЕ ОРГАНИЗА- ЦИОННОЙ КУЛЬТУРЫ МАШИНОСТРОИТЕЛЬНОГО ПРЕДПРИЯТИЯ}

Аннотация. Целью написания статьи является обобщение и практическое применение научных подходов к оценке организационной культуры предприятия, относится к машиностроительного комплекса. Используя методику ОСАИ удалось определить имеющийся и желаемый тип организационной культуры, положительно повлияет на повышение конкурентного статуса предприятия, а также на возможность эффективного использования трудового потенциала предприятия. Поскольку именно надлежащий уровень организационной культуры предприятия влиять не только на психологический климат в самом предприятии, но и даст возможность повысить эффективность его деятельности. Методика. Для достижения целей нашего исследования необходимо продиагностировать тип организационной культуры избранных предприятий и сделать выводы по изменению организационной культуры. Для успешного проведения диагностики организационной культуры предприятия воспользуемся инструментом оценки ОСАИ для определения ее фундамента. Данный инструмент оценки организационной культуры помогает достаточно четко определить организационную культуру, в которой члены предприятия намерены прийти, чтобы соответствовать требованиям и динамичным изменениям внешней среды предприятия. Предложенный инструмент для оценки организационной культуры на предприятии фокусирует внимание на стержневых признаках организационной культуры предприятия. Результаты исследования показали, что оценка организационной культуры с использованием методики ОСАИ дало возможность определить необходимый тип организационной культуры на исследуемых предприятиях. Практическое значение. Определение рекомендационного типа организационной культуры дало возможность руководству изменить стиль своего поведения и лучше замотивировать трудовой коллектив. Обратить внимание на существующие проблемы и улучшить психологическую обстановку в коллективе, а также повысить эффективность работы персонала предприятия. Значение/оригинальность. Полученные данные по четырем предприятиям позволяют сделать вывод, что именно данный метод оценки подходит для оптимальной оценки состояния организационной культуры предприятия. 